\title{
Man in Noosphere: Evolution and Further Development ${ }^{1}$
}

\author{
Sergiy Sonko \\ Doctor of Geographical Sciences, Professor, National University of Horticulture \\ (Uman, Ukraine) \\ E-mail: sp.sonko@gmail.com \\ https://orcid.org/0000-0002-7080-9564
}

The absence of the paradigm of the socio-natural development of the noospheric level is now confirmed by the almost complete fiasco of the concept of sustainable development (especially after Rio +20). The main reason for this is the incorrect positioning of the "Homo" species in the biosphere of the planet. "Ecotope" Homo Sapiens goes far beyond the organism level of the species organization and covers the ecosystem level, forming an agroecosystem, as an ecological niche with moving spatial boundaries. The reason for the aggravation of the global ecological problem is the spatial inconsistency of the territorial combinations of the noospheric ecosystems. As close to sustainable, the priority development of agroecosystems as socio-natural systems is proposed and the need to "inscribe" administrative-territorial division into their borders, since just then the content of interaction between nature and society will be approximated to the adaptive content.

Keywords: agroecosystem, biosphere, sustainable, ecological, noosphere

Received: June 4, 2018; accepted: August 10, 2018

Philosophy and Cosmology, Volume 22, 2019: 51-74.

DOI: https://doi.org/10.29202/phil-cosm/22/5

\section{Introduction}

After a long discussion that has lasted probably since the first reports of the Roman Club the main issue of nature management "Why is the global environmental problem still unresolved?" remains unanswered. Even the recent fundamental works on this problem [Yablokov et al., 2015, 2016, 2017] give a very weak hope for a constructive solution to it. Therefore, the authors in the first article of the cycle try to answer the question "What is going on?" [Yablokov et. al., 2015].These articles also give an unequivocal answer to the question "Who is to blame?" Of course, it is the Man [Yablokov et al., 2016]. However, in the third article of the cycle the search for the answer to the question "What to do?" did not

${ }^{1}$ The author unlike Arkady and Tatiana Ursul [Ursul\&Ursul, 2018] does not put an equal sign between the categories "evolution" and "development," understanding under the first retrospective of the Process [Khrutsky, 1999], and under these cond its perspective.

(C) Sonko, Sergiy, 2019 
give results. The authors state, "The modern discourse of social evolution ... is still at the stage of substantiating hypotheses and highlighting trends. All these efforts have not yet led to the creation of any full-fledged concept not to mention the complete theory" [Yablokov et al., 2017].

We risk asserting that such a concept (noosphere ecosystems) was developed by the author 15 years ago [Sonko, 2003]. Throughout the period of time after the publication of the monograph in the world, the author has repeatedly found confirmation of his ideas on the pages of scientific and popular scientific literature, as below.

As it is inherent in concepts, there are both elements of the hypothesis, as well as scientific facts, in it in various proportions, which are in numerous publications published over the years. Considering that this is a long process of human noosphere evolution, the publications used by the author with the corresponding references do not always belong to the last decade. In our opinion, "obsolete" data in the study of noosphere ecosystems, especially from the standpoint of evolutionary development, do not matter, because the correct interpretation of the Process of this development allows to "isolate" its main features at any stage. Therefore, the author asks not to be very meticulous to refer to a small number of links to the latest sources.

In our opinion, the methodological impasse of most modern works of the noosphere direction is explained not by the lack of an answer to the question "What to do?" but an incorrect answer to another main question "What is going on?" The answer to the second question "Who is to blame?" is so obvious that is not worth additional discussion and written on this topic of dissertations because it has been repeatedly given in the works of great thinkers since ancient times.

It would seem that the mechanisms of influence on the nature of the main culprit of the global environmental problem have long been described. In numerous works, it is conceptually "embedded" in the biosphere, which is gradually destroying. We can only create a Supreme Judge, catch the hand of offenders of the biosphere balance, mercilessly punish, re-educate, and in such a way build a desirable noosphere. It cannot be said that nothing was done in this direction. Actually, the Rio World Summit (1992) was the first step towards the creation of a World Government that would regulate human intervention in natural ecosystems. However, neither the concept of sustainable development which turned into a strategy, nor the Kyoto protocol, nor the formation of the ecological network developed in the future did not solve the problem. The global environmental problem only continues to worsen [Yablokov et al., 2015; Sonko, 2018b]. It is this undeniable fact that suggests that the correct answer to the main question "What is going on?" has not yet been found.

In our opinion, the methodological breakthrough in addressing the global environmental problem has become such recent achievements:

a) Development of the concept of the ecological footprint of mankind [Galli et al., 2012], which continues in a number of publications related to the idea of spatial redistribution of planetary resources [Sonko, 2003, 2018b; Sonko, Maksimenko, 2013] by the author of this article;

b) In-depth study of some of the functional characteristics of man as a form [Yablokov et al., 2016], in particular, the release of tertiary substance (in addition to the substances in Volodimir Vernadsky classification);

c) Significant approximation to a single environmental paradigm [Krushanov, 2001].

At one time, "having worried about" the ideas of post-non-classics (subject-subject relations between Man and Nature), the author came to a firm belief that we must go even 
further and build object-object relations in which the main object of the research and transformation should be not Nature, but Homo Sapiens and, for the most part, the biosphere behavior of this species. And it will depend on Man whether nature management will be as predatory, or nevertheless it will become biospheric tolerant and will provide a gradual transition to the noosphere, as an ideal of interconnection of Nature and Man.

By directing a retrospective view in the depths of the ages, we should not miss the issues of cosmology. In particular, it is important to know where, when and for what the Man "enters" this planet, and, most importantly, when he finishes its "victorious" progress in relation to the biosphere. The cosmological implication of the global environmental problem is knocking more loudly into the door with the real efforts of Elon Musk relative to the colonization of Mars, as well as the rapid development of space-oriented technologies. The author will make a mistake gladly but, as soon as possible, the time of our species on this planet is coming to an end. How exactly our species behaves on other planets is not difficult to predict by watching James Cameron's Avatar.

Attempts to find the cosmological content of the global environmental problem have a long history, from the works of prominent naturalists (Immanuel Kant and Volodimir Vernadsky, ets.) to contemporary philosophical works [Khrutsky, 1999; Ursul \& Ursul, 2018]. In particular, in the last work, everything that happens on our planet under the banner of evolution, according to the authors, is directly derived from the deep processes of the Universe: "The planetary evolutionary processes, this way or another, are related to the main trajectory of the continuous self-organization of material systems in the universe, which we called the superhighway of global or universal evolution" [Ursul \& Ursul, 2018: 39].

In the hope of fulfilling the expressed hopes and in the course of the teachings of Volodimir Vernadsky about the noosphere, the author is almost convinced that nature use since the Neolithic times has been noospheric. That is, a Man more than 10 thousand years "embeds" himself and his economy in the biosphere matter and energy mechanisms. In addition, it is thanks to man that the biosphere gradually evolves into the noosphere. However, the ecological danger of the primary and the present noosphere is radically different. If by 1900 , the energy consumed by mankind was $1 \%$ of the total energy flow of the biosphere [Arsky et al., 1997], which was close to the biosphere constants (Nicolay Timofeev-Resovsky, Nikita Moiseev ${ }^{2}$ ) and at the beginning of the $21^{\text {st }}$ century this value is already equal to $10 \%$. Thus, according to Victor Gorshkov, one of the fundamental laws of biospheric self-regulation has been violated by an order of magnitude [Gorshkov, 1995]. However, this was done by the Intelligent Man, the creator of the noosphere (according to Volodimir Vernadsky), having started socio-natural (noospheric) systems in the Neolithic Age. Therefore, the identification in space and time of such systems will help to determine where the person is now and how far it is "detached" from the biosphere on a hard and long way to the noosphere.

The author, as a geographer, has been studying the problem of «consumption» of geographical space by our species for more than 30 years (from postgraduate Lomonosov Moscow state university) and is convinced that the search for the correct answer to the "What

\footnotetext{
${ }^{2}$ From the memoirs of Nikita Moiseyev: "Once Nikolay Timofeev-Resovsky asked meto estimate how many inhabitants of the planet at the present level of technological development will be able to "fit"into the Biosphere natural cycles. After 3-month calculations, I got a number of 200-800 million." What Nikolay Timofeev-Resovskii replied: "Almost right. Five hundred and without any calculations. After all, only $10 \%$ of the energy that people use is renewable energy. The rest gives the repository of energy of the former biosphere. Therefore, in order not to spend non-renewable energy resources and to live in harmony with Nature, humanity must either find new technological bases of its existence, or at least reduce its amount ten times."
} 
is happening?" question is impossible without realizing the spatial-temporal existence of our species. Perhaps, after the publication of this work, the answer will be closer, and finally, it will become clear what to do. Perhaps the author's concept will become an effective tool in the hands of the future World Government to achieve its main goal — "the return of Man to the Biosphere"3.

In the process of forming ideas about the problem of the interaction of nature and society, the author became close to several literary works written in different years of the twentieth century. It is an era when the global ecological problem became quite tangible. They are "My brother Alexei's trip to the country of peasant utopia" Alexander Chayanov, "The Unplugged Planet" Garry Garrison, "Futurological Congress" by Stanislav Lem and "Generation-P" by Victor Pelevin.

By Alexander Chayanov, humanity will be able to live on this planet much longer if it eliminates the city as a "social creature."

According to Stanislav Lem, if a person continues to exploit natural resources at the same pace, he will wait for a lunch from a gray, misleading biomass, masked by psychotropic drugs "as a chubby" and underground and above-ground skyscrapers with anthropogenic desert around.

According to Garry Harrison, human civilization can survive on any planet, provided that the "iron guards" find a common language with the "messengers", stopping in advance a losing struggle with wildlife, since the victory over nature will always be Pyrrhic.

According to Victor Pelevin, a modern man ("Homo zapiens") is a being spiritually separated from nature and duped with switching buttons on numerous consoles and appears on the light to consume in quantities brought to the absurd.

Actually, the content of these works is the literary basis of the author's point of view on the problem and their reading will help the reader to understand the essence of the noospheric ecosystem concept far from the scientific maxims.

From a scientific point of view, the return of Man to the Biosphere on the principles of a natural economy is a realistic procedure, which requires a complete and final awareness of the biosphere essence of the Homo sapiens species. We can begin to talk about the noosphere after realizing that a person living on the planet Earth can never be excluded from the matter and energy flows of the biosphere. In another language, only after we learn to swim (live in harmony with biosphere interests), we will pour water into the pool called "Noosphere".

\section{Evolution}

The author is inclined to interpret the mechanisms of exacerbation of the global ecological problem within the evolutionary process in the categories and concepts of the paradigm of natural history. It was initiated in the works of Immanuil Kant, Charles Lyell, Charles Darwin, Karl Ritter and others and continued by Volodimir Vernadsky. By adding some modern ideas, we will outline its main features:

- The development of our planet is derived from the energy information processes of the Cosmos [Khrutsky, 1999; Lazarev, 2000; Yuzvishin, 2001; Ursul \& Ursul, 2018].

- For a certain time on our planet there was a fixed amount of matter and energy (the law of physical and chemical unity and the constant amount of living matter by Volodimir Vernadsky). This is also the law of constancy, which determines that the amount of living matter of the biosphere for a certain geological period is constant. According to Nikolay Reimers, it is a quantitative consequence of the law of internal dynamic equilibrium on the

${ }^{3}$ Statement of Boris Rodoman from an introduction to the author's doctoral dissertation. 
scale of the global ecosystem - the biosphere [Reimers, 1994]. In accordance with the law of biogenic migration of atoms, since living matter is an energy mediator between the Sun and the Earth, either its quantity must be constant or its energy characteristics must change. However, the law of physical and chemical unity of living matter eliminates significant fluctuations of the latter. Therefore, the quantitative stability of living matter is inevitable. This makes the law of constancy of living matter in conformity with the law of conservation of the structure of the biosphere by Goldsmith Edward. In the future, both with the participation of planetary-space processes and populations of living matter on the planet, the transformation of matter through its redistribution in the planetary space is carried out. The most intensive redistribution is carried out by the human population.

- According to the law of ecological order or ecological mutaulism (third law of Goldsmith's ecodynamics) which is named by Nikolay Raymers "the law of ordering the filling of space and spatial-temporal certainty", filling the space inside the natural system through the interaction between its subsystems is arranged in such a way that allows to realize the homeostatic properties of the system with minimal contradictions between its parts. Any enemy component random or artificially made by man in the system will be eliminated by him, or in order to support its existence, the system will require additional energy resources. It is through the use of additional energy resources that the law of ecological order is violated by man, since filling the ecological space (in the final sense, the ecosystem of the planet) takes place in the direction of its structuring that is not inherent to natural ecosystems [Yablokov et. al, 2015, 2016].

- The above does not exclude and unnecessarily proves the spatial "integrity" of the Homo sapiens population in the space of the biosphere. Therefore, the human population in terms of biology should have its habitat/ecological niche, which can be traced, both in space and in time. Such area is agricultural ecosystem (Fig. 1) [Vavilov, 1987; Gumilev, 1997; Sozinov \& Sonko, 2006; Hagget, 1968].

- At a certain stage of development, the structure of agricultural ecosystems is intensively informational which leads to the subsequent allocation of urban ecosystems from them with much simpler artificial material-energy-information links but with much greater ability to redistribute geographic space in its favor.

- The main purpose of the evolutionary process is more logical to consider not the achievement of "civilization" " and a certain level of material-energy-information transformation of the geographical envelope to the limit from which active life leaves the planet. Since the "axial time", such an active transformation is carried out by a human population.

- The primary spatio-temporal unit of awareness of the evolution of man as a species is better not to consider "civilization as a regional, self-sufficient and autonomous selfdeveloped, supernatural socio-cultural system, determined in space and time" (according to Arnold Toinbie) and an agricultural ecosystem as an objective, capable of developing the spatial-temporal form of the planetary (ecological-noospheric) existence of a person which is necessarily formed in the process of noosphere genesis. In general, the consideration of the evolution of Homo sapiens species in terms of ecological systems science, rather than the civilization process, is more correct.

- The evolutionary destiny of mankind is the relay of material-energy-information flows from our planet to the cosmos which development is historically drawn: "This grand

${ }^{4}$ According to the theory of the biosphere-noosphere by VolodimirVernadsky, responsibility for furtherexistence of life on the planet isassumed by a Homo sapiens, whose "wisdom" is now interpreted as "civilization". 
planetary-cosmic process was developing with people participation and has the potential to extend human activity into the Universe" [Ursul \& Ursul, 2018]. The entire retransmission system has its own history and began when humanity, as a species, began to use actively other species from their ecotopes [Sonko, 2010].

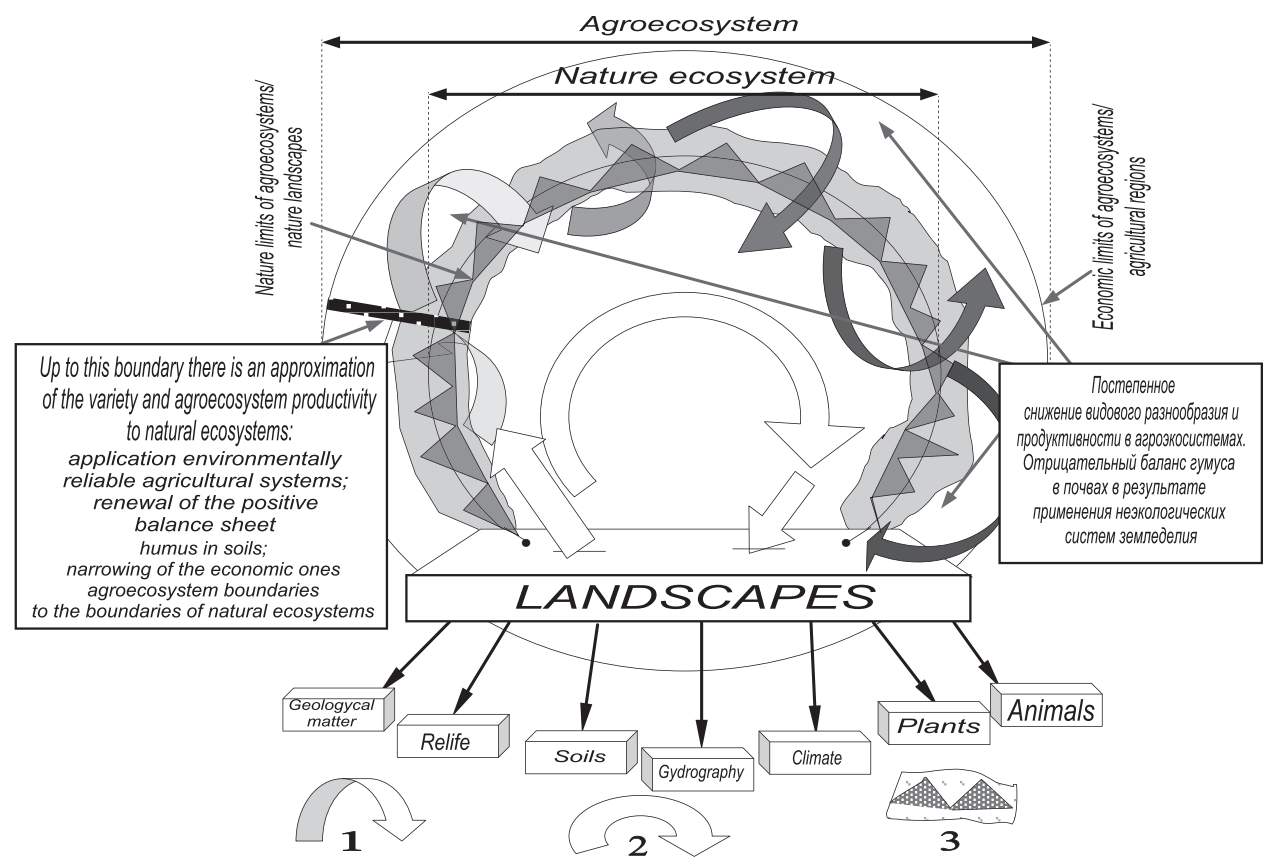

Fig.1. The dynamics of agroecosystem formation

Legend: 1 - streams of matter and energy, which are formed in agroecosystems; 2 - flows of matter and energy, which are formed in natural ecosystems; 3 - zone of the moving boundary agroecosystem.

- The "redevelopment" of the earth's surface by Homo sapiens gradually led to a certain structuring of it that is embodied in three forms of the territorial structure - the areal, the focal and the communicative one.

- The oldest and the most stable ones on the sustainability of development are communicative elements or infra ecosystems (from the "infrastructure") which provide the material basis of informatization, forming a variety of communication structures. Agricultural ecosystem is the second in a sequence of development of the form of a territorial structure that structures the earth surface in the form of radically transformed area with redirected materialenergy-information flows by a human. From the environmental point of view, agricultural ecosystems are the main spatial forms of noospheric human existence, which exist to this day. In the process of their development, at a certain stage of excessive accumulation of information, urban ecosystems are spatially separating 5 .

5 "Distribution area" of one Homo sapiens species should cover a certain area. If this area for some reason decreases (either as a result of fertility or as a result of immigration), the formation of the urbanecosystem as a "regulator" of relations "area — the number of individuals". "Hinterland" or the zone of influence (regulation) can spread over much longer distances by performing the functions of "world cities" which in the end areal so reduced to the regulation of plane proportions. 
- The evolution of agricultural ecosystems in the geographic space originates from the "spreading out" of the gene pool of cultivated plants by the entire surface of the planet Earth [Vavilov, 1987]. In obedience to the fundamental law of the genetic and informational unity of life, the memory of systems of all levels of organization of living is genetic: on the organism level it is genotype, on the population level it is the gene pool (functional set of genotypes of individuals that are in its composition), the ecosystem level it is genoplast (functional combination of gene pools of all populations and genotypes of all organisms that are part of the ecosystem, that is, the hierarchical combination of regulators of systems of the population and organizational levels of the organization). The memory of living systems also functions as their cybernetic controller, that is, the main structural block of self-regulated systems, which, along with the reference system, direct and feedback channels between the regulator and the controlled system provides the effect of their self-regulation [Golubets, 2000]. Consequently, in agricultural ecosystems there is the "memory" of the former structural and informational unchanging biosphere. According to modern notions of rhizome [Deleuze \& Guattari, 2005; Grodzinsky, 2014], ${ }^{6}$ such memory is the soil.

- Such "memory" at the level of agricultural ecosystems ensures self-regulation of the "human ecosystem" due to the direct regulation of the size of the human population (disease and war) and indirect influence on the planetary spatial structures (regulation of the initial relationship between the area with the rural areas and agricultural lands). In particular, it is due to the preservation of certain proportions between territories with "naturalized" and "commodity" economy ${ }^{7}$. One example of the social manifestation of the process of selfregulation is terrorism which general spatial direction is described by the armed response of the so-called "third", "uncivilized" countries to the resource, spatial and information expansion of the "developed" countries with the Western European type of civilization (New York, Bali, Moscow, London, Paris and to be continued).

- From the geographical position, at the beginning of the separation of urban ecosystems, their main "information load" was to provide deeper structuring of the geographical space due to intensive metabolic processes with agricultural ecosystems that they "spawned" with other urboecosystems. The beginning of radical structuring of geographic space historically coincides with the "axial time". It was when urban ecosystems began to carry out actively modern functions of generators, drives, transformers and repeaters of diverse information.

- The modern "information load" of urban ecosystems consists in the concentration of information flows at certain points. They are poles (according to Walter Crystaller, Fransua Perrue, Boris Rodomann and Vyacheslav Shuper), the earth's surface ("world cities") for the formation of a continuous global information field [Sonko 2003, 2010, 2013]. In this case, non-living substance (according to Volodimir Vernadsky) in the process of noosphere genesis becomes the main battery and transmission link between natural and semi-natural ecosystems (agricultural ecosystems). The information about the previous qualitative states of the human population is accumulating in it (tools, structures, mechanisms and computers). Thus, above all, "anthropogenic process" of our planet is connected with the change of the leading "carrier" of information. In nature, such carriers are predominantly living matter and accumulators are semi-solid matter (soils); in the anthroposphere, the technospheric elements

${ }^{6}$ The notion of rhizomeas a system - creating pattern not only of the landscape, but also of socionatural interaction was expressed by Mikhaylo Grodzinsky at an open lecture at the Faculty of Ecology of the Kharkiv Vasily Karazin National University on February 27, 2014.

${ }^{7}$ The French social philosopher Raymond Aaron points out the contrast in the his torical process of the traditional agrarian society, where the natural economy and estates were dominated the industrial society with commodity - market production and the liberal-democratic political system. 
of their combination have the role of batteries and transport and communication channels (infra-ecosystems) have the role of carriers.

\section{Civilization and noosphere genesis}

At one time Volodimir Vernadsky came to the idea of the noosphere, as the sphere of reason, that is, such a state of the biosphere, when Humanity will understand its inevitable negative role on our planet with a great caution. Hence, the author's understanding of noosphere genesis, as "the process of awareness of the human inevitability of its influence on the natural systems of any planet" [Sonko 2010].

1. Any "civilization" (regional or global) represents the whole ecosystem in its classical sense. It means that it is not only the spiritual (socio-cultural), but also the very real material body which constantly carries out a substantive energy-information exchange with the environment, other systems and with each other and in the spatial aspect it is both with the surrounding planetary geographical space and with The cosmos. At the same time, the material consequences of the life of civilizations from a certain territory are not going anywhere. They contribute to the overall process of "noospherization", "depositing" with depleted soils, abandoned elements of the technical sphere and distorted material-energy flows in ecosystems.

2. The civilization concept tries to interpret the information block of such an exchange, since the active transformation of mankind into the biosphere. Socio-cultural achievements testify to the accumulation of information at its gradual transition from lower levels of the state of matter (according to Volodimir Vernadsky), to higher ones which are gravitational, electromagnetic, torsion and other fields and gluon formations [Shvebs, 1998; Bazaluk, 2016]. This transition is "stretched" in historical time in accordance with the most important technological inventions [Baburin, 1999].

3. Evolution of the development of physical representations about the structure and state of matter is the main theoretical foundation of many sciences but, mostly, natural ones. The remoteness of history from them explains the lack of natural landmarks of socio-cultural development in the civilization concept. On the other hand, the "power" of the civilization concept is seen by many scholars in the fact that in it a person and especially a human society (in various ways of interpretation: "ethnos", "social medium", "regional civilization", etc.) has unique privileged position against the background of the historical process. In the tradition of the civilization concept, Humanity in the broadest sense is the God-chosen population, designed to be "cultural", "civilized" and intended to carry out spatial expansion first on its planet and then on others. This approach emphasizes the "uniqueness" of the human population and thus, in the minds of many scholars, "pulls out" nature from the evolutionary scheme of its interaction with humanity.

4. "Civilization" and "civilization process" are what researchers want to see convinced of the undoubted primacy of mankind in mastering the resources of the planet. At the same time, the development of culture, including the technical one, and religion are put forward as a main argument in favor of such a championship. In particular, the basis of the separation of the "axial time" is the very radical transformations in the cultural and religious sphere of human development. In today's works on countries "break-up in time" different states of "civilization", it is not paid attention on the ethnic groups, which do not seek to "civilization", obeying the way of life that existed for millennia. 
5. "Civility" in our eyes collapses as the form of human existence intolerant to the natural ecosystems. Anthropocentrism, laid down in this term, gives rise to classify separate ethnic groups and even entire countries from the standpoint of "civilization" as "civilized" or "uncivilized", "developed" or "underdeveloped". That is why in the public consciousness and reality there are superpowers that take on the role of "raising" other "non-civilized" countries closer to "civilization" (possibly through military coercion). However, the biosphere role of Australian Aborigines or "primitive" naturalized communities in South America is much more positive than superpowers. It is just as the division of animals into "higher" and "lower" animals. However, the role of these "lower animals" in maintaining the stability of the biosphere (decomposers) is much more positive than "higher ones", including Homo sapiens species.

Therefore, the system of spiritual and ethical values of humanity should be based on the principles of observance of biosphere interests. It requires a deep understanding of its place (humanity) and, consequently, the degree of participation in biosphere processes. Thus, humanity must not separate itself with the boundaries of globalist, post-industrial, civilization and other concepts from the processes taking place in the biosphere with the course of its evolution.

\section{Philosophy of history}

The geographic space should be integrating and combining start in comprehension of the historical process in which there is the process of interaction between nature and society. Here there are two fundamental approaches. The first one gives an idea of the process of life on the planet, which resulted in a distinct form of Homo sapiens; the second one is about geographic space as a connecting start of everything that develops on the surface of the planet, including the interaction of nature and society.

With regard to the first approach, there are new, more or less acceptable perspectives on the existence and development of the "process". According Konstantin Hrutsky (1999), it is possible to treat differently the "entrance" in the evolutionary "process" of life on the planet Earth but on the "exit", we surely have a universal and integral arrangement of the organization of Life on Earth. Further, the laws of logic steadily lead us to the following conclusion: if at the exit we have a single holistic process, then, of course, we have a single and universal program of the existing process. Equally, if the exit is a universal, single and integral phenomenon, then it logically follows that both the entrance to the process and the process itself are uniform, universal and coherent.

Moreover, if the entrance (the origin of the process) and its single and indivisible past (process) and the present (exit that is, today's reality of the process) constitute a universal whole, then there is no reason to deny this (universality and integrity) and the Future process. In other words, it is enough for us to find out the laws of the existence and development of a single process (the evolutionary process of development of Life on Earth) and we get a clear idea of natural stages of its future development. In other words, the Process is an objective reality, unknown to us in its origin, but which actually exists and is accessible to the current philosophical and scientific study and knowledge. The most significant properties of the Process are: a) its cosmic origin; b) possession of the essence of an autonomous ascending evolutionary process" [Khrutsky, 1999].

Consequently, the notion of the presence of the Process gives the right to "describe" the global macro-civilization system (as a prototype of a noosphere human being) to a 
progressive-evolutionary model of development. The main approach, which should be placed in the progressive-evolutionary model, is ecosystemic [Sonko, 2010].

1. Prehistoric time of the development of the biosphere (before the appearance of man as a species) is natural ecosystems [Biosphere, 1988];

2. Ecosystems of collectors gradually "come out" with the advent of man from natural ecosystems;

3. Agricultural and animal husbandry or agricultural ecosystems gradually "come out" from collector systems;

4. Urban ecosystems gradually "come out" from agricultural ecosystems.

5. An attempt to dissociate the historical process at the stage is the most vivid embodiment of reductionism in philosophy of history. Is the "civility" of history the main feature (criterion) that will help to see the retrospective and prospect of this process? It is unlikely. Ecosystems even in their modern sense existed before the "arrival" of man. However, when he "came" [Reteyum, 1987], he began to change over all directions of material-energy flows in the food chain of ecosystems in his favor which highest manifestation was the formation of cities [City-ecosystem, 1997]. Despite this, today natural ecosystems still can be found with the participation of man in the form close to the "first-nature one" (Amazonia, Equatorial Africa and Australia).

6. According to Karl Jaspers, the development of civilization was due precisely to the spiritual development of mankind. This gives grounds to consider the birth of civilization (axial time) the first step in the direction of the noosphere. At the same time, the first step towards "civilization" is the first step towards the destruction of Nature. Thus, "noosphere genesis is the process of awareness of humanity of the inevitability of its negative impact on the ecosystem of the planet" [Sonko, 2010].

7. Civility from the very beginning and, especially today, is imbued with anthropocentrism. At the same time, "CIVILITY" in the minds of most people means progress, that is, a movement towards better future. Awareness of the relativity of "civility" and "progress" acquires enough tangible features in the "Reports of the Roman Club". It is no coincidence that the sustainable development strategy launched in these reports and passing through the Rio 1992 almost died in Johannesburg (2001) and completely "crashed" in Rio + 20 (2012). It was in Johannesburg that the "sustainable" or "supported" development, at the demand of the backward countries, sought to "draw" "human development" (HDI) artificially. This means everything that embodies the "civility" of Western European representatives for traditional communities living in the backward countries. As a result, instead of the restrictive content, today's version of the Strategy for Sustainable Development has acquired features of the modernized Communist Party Manifesto.

\section{Global environmental problem in space and time}

Proceeding from the above vision of the paradigm of natural history in its historiosophical sense, it is necessary to outline the main theoretical positions that can be used as the basis for the constructive solution of the global environmental problem.

- With the course of evolutionary development of mankind on the planet Earth, there were significant spatial transformations of its surface. The present stage of these transformations is described by complex information processes that in turn form the corresponding materialenergy flows. Thus, the modern "globalization" of the production of social life is carried out under the slogans of the civilization process that seems to be able to bring the backward 
countries to better fate. At the same time, with the help of the system of repeaters there is a spatial redistribution of diverse resources in the interests of developed countries through indirect influence on the resource potential of the planet (including through the mechanisms of the Kyoto Protocol, the establishment of WTO various quotas, restrictions, embargo, etc.).

- The function of urban ecosystems is to redistribute (structure) the earth's space through information expansion. According to the concept of Ambartsumyan-Lazarev, the Sun complicates the communication with the Earth, "pushing" away from it. Actually, this process continues to this day in the direction of the information complication of the geographic (terrestrial) space. Information flows coming from urban ecosystems directly affect the course of world history. That is why the civilization process should be regarded as a certain period (a qualitatively new stage) for much longer Process [Khrutsky, 1999]. The information processes of the Universe were the basis of this Process that lasted until the "axial time". They found incarnation in the origin of the biosphere, its subsequent complication and its radical transformation by Homo sapiens-zapience (Victor Pelevin), due to the spatial redistribution of substance and energy flows and the subsequent exit beyond the boundaries of the earth's biosphere into space. Thus, not the civilization process is the basis of the evolution of the biosphere/noosphere but the gradual complication (squeezing) of the geographical (terrestrial) space in which man plays more active role than other species.

- The theory of the biosphere-noosphere Volodimir Vernadsky, as an attempt to find Man's place throughout the process of information complication, has its predecessors and successors. Actually, it belongs to the so-called extreme ideal models that outline the orientation of the development of any processes and phenomena. Literally, the theory of the biosphere-noosphere Volodimir Vernadsky is the ultimate ideal model of the development of the biosphere for the case when Humanity "gets smart". Predecessors of Volodimir Vernadsky in spatial sciences developed more narrow models: Johan Tyunen — it is "distribution" of agriculture in an "isolated state"; Alfred Weber - it is a "standard" of industry in its presentday likeness of an "isolated state" with only three "orientations"; Walter Crystaller — it is development of resettlement systems on an isotropic surface. The development of such models is similar to the research with the finding of world constants (absolute zero, acceleration of free fall, speed of light, radiation of an absolutely black body, etc.). However, in our case, these constants are spatial. Followers of Volodimir Vernadsky among geographers are Boris Rodoman (model of polarized landscape), Olexander Topchiev (theoretical model of rational territorial organization of nature, population and economy) [Topchiev, 2001].

- The development of ideal models of spatial organization can have a continuation in the search for spatial equivalents of time, energy and information, based on even existing preservation laws. Proceeding from the assumption that the amount of planetary space is constant (an invariant), it is possible to search for the excess segments (clusters) of space that arise in the process of noosphere genesis as a result of man's creation of "traps for time" and "traps for information" [Sonko \& Maksimenko, 2015]. ${ }^{8}$ Thus, it is possible to calculate the corresponding coefficients of "excess" of the invariant. Today it has been proved that developed countries (G-7) have the highest coefficient of "use (distortion) of space" (spatial entropy) which actively structure it [Pozdnyakov et al., 2003].

- The so-called "global environmental problem" is the result of the spatial mismatch of territorial combinations of different types of "hugging" the space of ecosystems - agricultural

${ }^{8}$ An example of "traps" for time is processed, preserved agricultural products, which, due to changes in biophysical properties, do not spoil over time. A typical "trap" for information is the change in the genetic characteristics of agricultural plants and animals in order "to educate" their best abilities: the reaction to drought, the increase of biomass with the use of certain biochemical additives, etc. 
ecosystems, urban ecosystems and infra-ecosystems. Hence, it is quite logical to perceive the search for optimization models of the territorial organization of society, which traditions have long existed in spatial sciences (Johan Tyunen, Walter Crystaller, Torst Hegerstrand, Fransua Peru, Boris Rodomann, Olexander Topchiev).

- Higher "informatization" will predict an over-saturation ("squeezing" by MyronenkoSorokin) [Mironenko \& Sorokin, 2001] of geographical space with various combinations of noosphere ecosystems at some stage. It will lead to qualitatively new shifts in the spatial existence of mankind. Most likely, such shifts will lead to two major directions of reducing the level of squeezing the geographical space. The first extensive direction is artificial delay in the time of the critical limit of compression due to the development of optimization models of geographic space (Fig. 2); the second intensive direction is the gradual formation of artificial ecosystems in the extraterrestrial space [Yuzvishin, 2001]. Thus, the development of future technologies will be linked to the first direction with the continuation of raw material expansion of developed countries in relation to the backward ones; the second direction is with the rapid development of space-oriented technologies.

- By introducing an extensive way of further development that is more realistic for the near future, it is expedient to optimize the geographical space in the direction of rotation of individual groups of elements of the territorial structure and their functions (Fig. 2) [Sonko, 2006].

- Taking into account the selection and modern historiography of the so-called "axial time", it is expedient to find biosphere analogues of this phenomenon. In our opinion, the invention of the plow by the Romans, its improvement by Karl Sax and the subsequent plowing with the flipping of a chunk is a kind of "axial time" in the noosphere development of mankind. It was then that the first steps towards the deliberate destruction of the biosphere were made. This led to the fact that at the beginning of the 21 st century, carbon dioxide emissions from world agriculture exceeded its emissions by burning all fossil fuels by $10 \%$ [Losev, 2003]. However, in the late 19th century, this tendency became a noticeable conscious allocation in the structure of the crop area of fodder arable land [Sonko \& Maksimenko, 2015].

- The entire pertinent history of mankind is the history of the gradual departure from its ecotope. The main purpose of such "civilization development" is to obtain surplus "substances of nature" which are obtained through the achievements of so-called scientific and technological progress. Therefore, it is logical to have the skeptical view of the "cultural landscape" [Gorshkov, 1995].

- The above ecosystems are noospheric and form a modified ecological niche of Homo sapiens with fundamentally modified edaphic component [Sonko \& Maksimenko, 2015].

As a result of the existing spatial dynamics of Homo sapiens, the information influence of urban ecosystems («hinterland») on the surrounding space is gradually increasing due to the tools of information infrastructure. Hence, in fact, the name "infra ecosystem" comes from. At the same time, the highest level of information influence, leading to the growth of planetary entropy, is inherent in today's so-called "world cities".

Such an influence has a manifestation in the diversification and inverting of geographic space. According to the results of the author's research, as well as according to Vazhenin [Vazhenin, 2002] and Yakovleva [Yakovleva, 2002], the territories that are hinterlands of the nearest "world" or higher "central" places are forcibly turned into servicing or infrastructure ones [Sonko \& Skrynko, 2004]. Consequently, in the theory of Walter Crystaller, central places have always performed non-serving and deverifying functions "redistributing" the geographic space in their favor. 


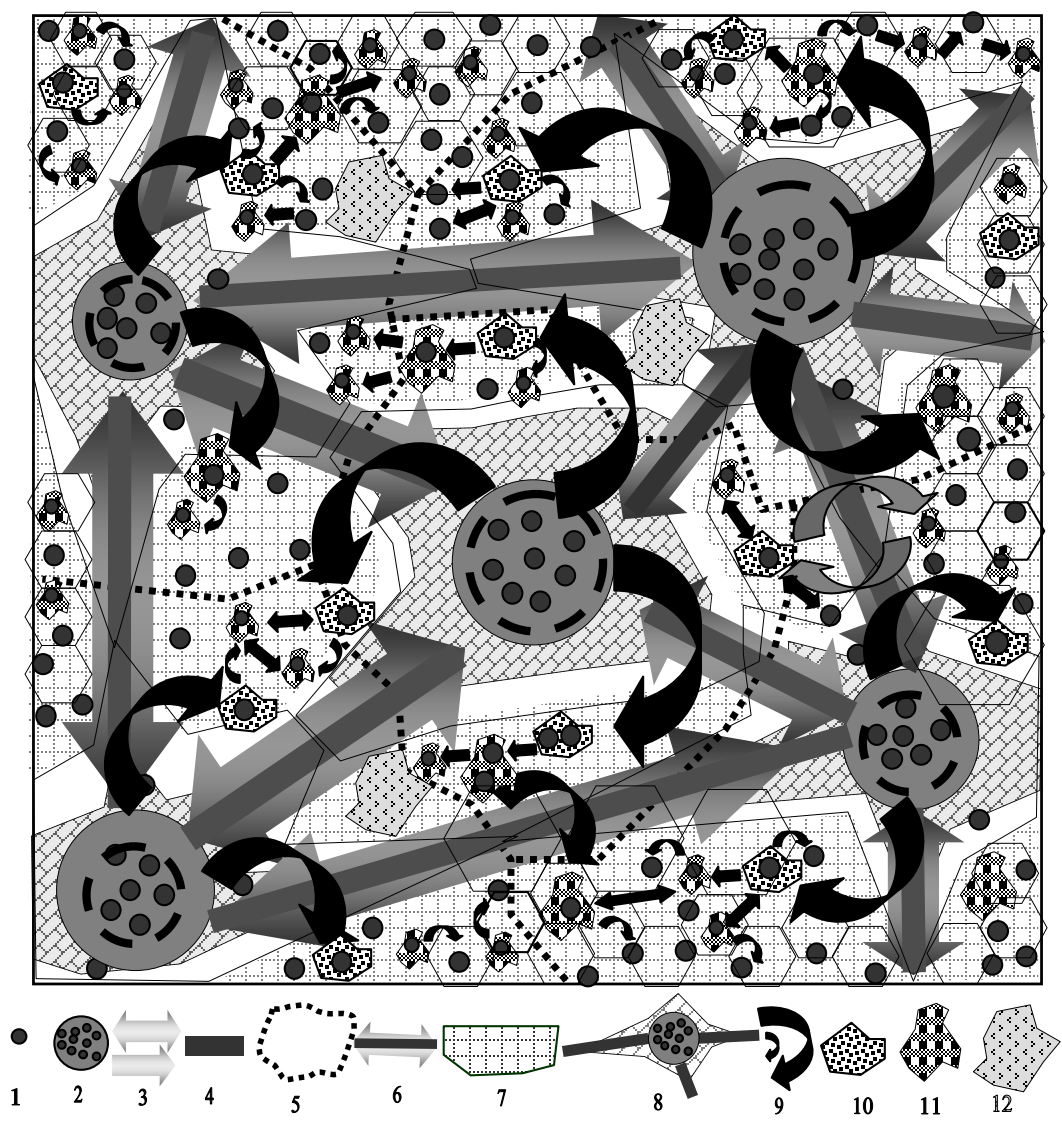

Fig.2. The ideal model of socio-natural interaction in the process of nature management, based on the principle of spatial rotation.

Legend: 1. an individual species of homo sapiens; 2. urban settlements; 3. information channels; 4. modern ways of communication; 5 . fields of influence of stationary settlements; 6 . Infrastructure ecosystems; 7. agroecosystems; 8. Urboecosystems. 9. directions of spatial rotation of functions of agro- and urboecosystems. 10. ergo landscapes, agro-recreational parks, «dendro» and «aquapolis» as centers of desurbanization; 11 village villages; 12. ecological network objects.

\section{Formation of the ecosystem of Man and its n-dimensionality}

The process of interaction of nature and society (movement) in a planetary space-time appears in the form of two of its main components: nature and society. Together, they actively fill the geographical space from the Neolithic Age, which gradually leads to its "squeezing" [Mironenko \& Sorokin, 2001].

Considering the process of noosphere genesis as forming in a certain frame of reference, it is logical to conclude that the squeezing of the geographical space must be compensated in real time, as already written by separate geographic works [Mironenko \& Sorokin, 2001; Rogachev, 1999]. For such compensation, a person creates "traps for time" as if putting it "for later". Largely, humanity took in nature "in debt" time to which it "outstrips" it in 
the course of its development [Sonko, 2006]. Stages on Fig.3 meet conceptually significant indigenous milestones in the interaction of nature and society.

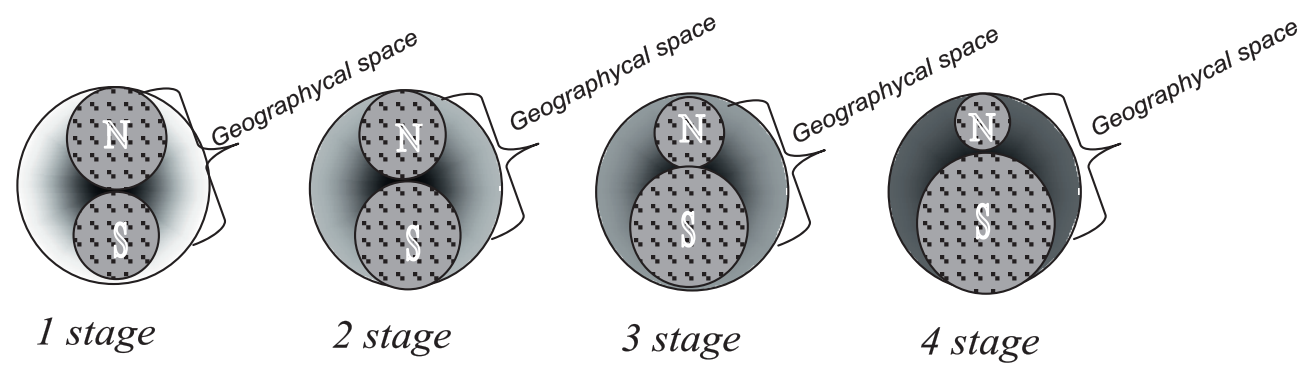

Fig. 3. The main stages of the interaction of nature $(\mathrm{N})$ and society(S) (spatial and temporal slices). Different tones of gray color show a different degree of «squeezing» of geographic space

The first stage corresponds to the "isolation" of the species from another living nature in the beginning of anthropogenesis. From the second stage (Neolithic) the active structural modification of humanity to the surface of the planet began. The third corresponds to the beginning of the development of industrial civilization, when Man with various mechanical devices greatly increased the rate of structural and material-energy modification of natural ecosystems. From the standpoint of the theory of the noosphere by Volodimir Vernadsky, the optimal interaction of nature and society corresponds to the second stage. However, at the same time there should be a virtual "expansion" of the geographical space due to its squeeze under the action of "infra-ecosystems". The fourth stage is a borderline on the verge of abandonment of the intelligent forms of life of our planet, or the formation of cosmic ecosystems [Sonko, 2003].

According to the author's concept, one of the main causes of the emergence of an environmental problem lies at different rates of development of nature and society. The result of this difference is necessarily "postponed" in the geographic space. Such "prints" are either vivid or obscured by the observer's eyes. This is related to the double nature of the boundaries of agricultural ecosystems (Fig. 1, 4). In our case, agricultural ecosystems that are formed on the territory of Kharkiv region and those having a double character of the borders (fig 1), can be "found" in space. Thus, in the projection (imposition) of any two-dimensional or even three-dimensional geographic objects, one should expect formation in the "fourth dimension" of new quality spatial formation (Fig.4). The logic of this representation is shown in the figure hatching in the cell ( $4 \mathrm{a}$ - two-dimensional option); in the picture ( $4 \mathrm{~b}$ - threedimensional variant) it is Upper Body. This may be the boundaries of landscape complexes, boundaries of ecosystems and agricultural areas.

Actually, the "run-off" of these limits testifies to different speeds of development of nature and society. For a constructive solution to the "global environmental problem", it is necessary to find such areas of space, which reflect the difference in the velocities of nature and society and, subsequently, gradually reducing them, lead to optimal relations. In addition to the real territory (Kharkiv region) as a result of the study of the spatial dynamics of agricultural ecosystems, the author found such "segments" of time "borrowed" and reflected in space (Fig. 5). 

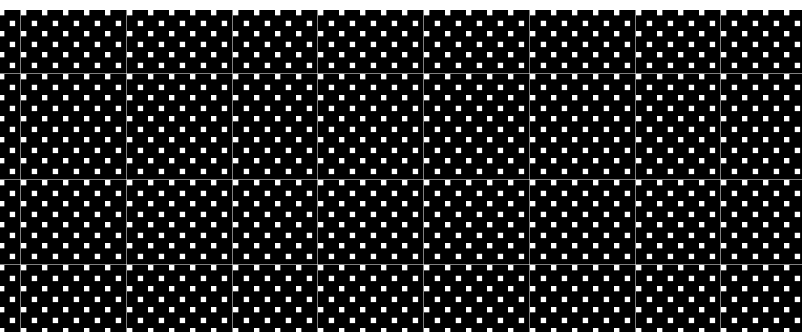

Fig. 4. Formation of a qualitatively new spatial n-object by projection of several twodimensional or three-dimensional objects. a) two-dimensional projection; b) general view.

Continued research on trends in agricultural ecosystem formation on this territory for 30 years in a row revealed certain tendencies that confirm the probability of the author's concept [Sonko, 2006, 2018a]. In particular, the simplification of the substance-energy relations in agricultural ecosystems (mono cultural specialization) led to their spatial consolidation and hence to greater "exit" out their own natural boundaries. (Fig.6).

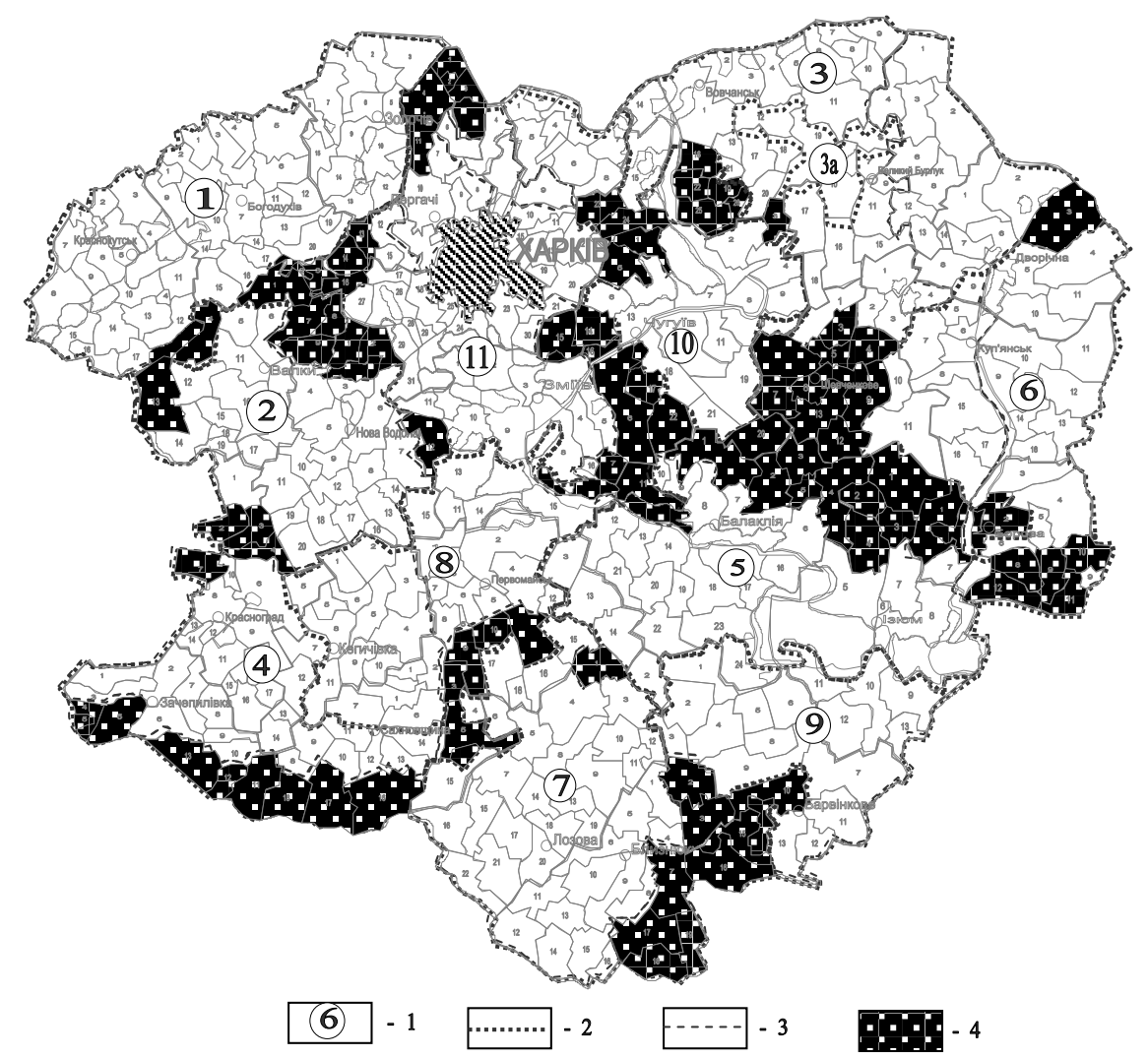

Fig. 5. Formation of zones of entropy tension.

Legend: 1. numbers of agricultural areas; 2 . the boundaries of agricultural areas (economic boundaries of agroecosystems); 3 . boundaries of the types of organization of the territory (natural boundaries of agroecosystems); 4 . Areas (segments) of the space, on which «the» do not match «the natural and economic boundaries of agroecosystems 
If in 1985 in Kharkiv region there were 11 agricultural districts which boundaries correspond to the economic boundaries of agricultural ecosystems, in 2015 there were only 7 ones. At the same time, urbanization is intensifying against the backdrop of desertification of rural areas. That is, the zones of influence of urboecosystems (Fig. 2) continue to expand causing further aggravation of environmental problems.

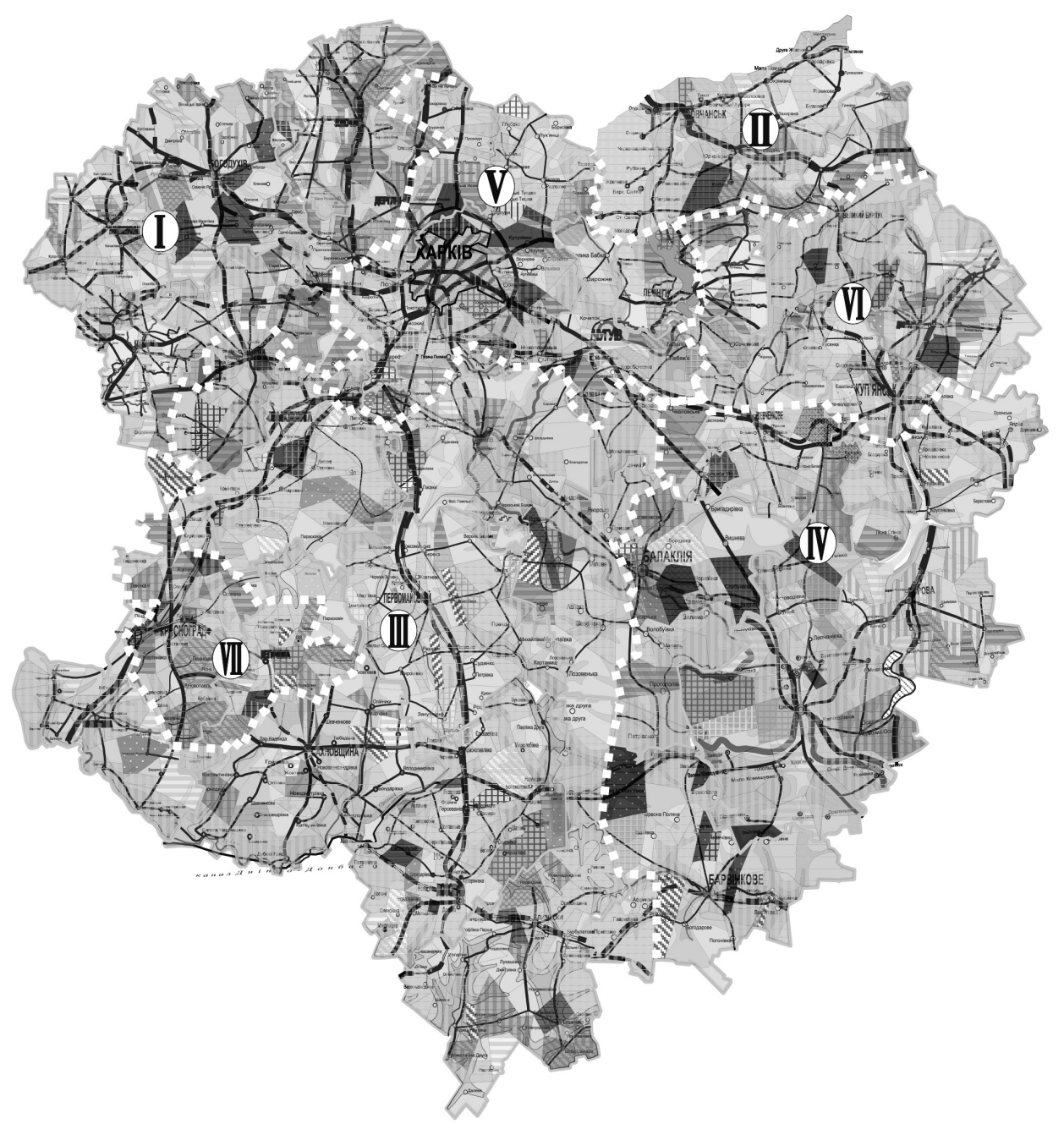

Fig.6. Modern boundaries of agroecosystems that are formed in the Kharkiv region (2015) [Sonko 2018a]

According to the classical (Sergiy Podolinsky) and modern ideas (Viktor Rachkov, Dgeremy Rifkin, Viktor Gorshkov, Viktor Pismak, etc.), such "disagreement" leads to an increase in the level of planetary entropy, and, therefore, to informational "tension". It is the fastest cause for not only ecological but also many other "global" problems. In particular, a high correlation between the degree of coincidence of natural and economic boundaries of agricultural ecosystems and the balance of humus in soils is established [Sonko, 2006]. 
The model (Fig.2) describes the general direction of the transformation of geographical space by Homo sapiens in the direction of reaching the noosphere state. At the same time, the current state of this dynamics is characterized by constant squeezing of the geographical space under the influence of world cities. In parallel, the process of distorting geographic space is due to spatial inversions [Rogachev, 1999] which main consequence is the deepening negative balance of natural resources (so-called "environmental problem"). There is also a redistribution of spatial localization of the entire population, in particular, the deepening of disproportions between the population of large cities and the corresponding depletion of rural areas [Vazhenin, 2002].

\section{Discussion}

One of the main noosphere provisions of the ecology of Homo sapiens should be that this species is an equal participant in the natural substance-energy cycle but it has expanded boundaries of its ecological niche due to timing of natural processes ("time traps") and the spatial transformation of its ecotope ("space traps"). In addition, such spatial-temporal transformation significantly increased the degree of planetary entropy ("traps for information") [Sonko, 2006].

- Homo sapiens in the process of its vital activity in the Earth's biosphere forms identical edaphic (spatial) formations by ecological features with other species and takes on the same participation in food chains, occupying its trophic level in radically rebuilt but natural ecosystems. Therefore, it is more logical to say about the agricultural ecosystem as an ecological niche of Homo sapiens with vaguely defined (moving) spatial boundaries. So, there are no grounds to consider the agricultural ecosystem Homo sapiens as unnatural ("semi-natural", "combined", "artificial", "anthropogenic", "technogenic"), based on the presence of the "second nature" of Man. All ecosystems, including anthropoecosystems (or noospheric ones), are "primordial".

A possible way of harmonizing the development of nature and society may be the spatial rotation of the functions of agro- and urban ecosystems while maintaining the bundle functions of infra-ecosystems and the desire for the contact type of delimitation [Sonko, 2003, 2006]. In addition, the cells of "delaying" a certain number of urban population could become areas of "unchanged" nature in which (according Konstantinos Doksiadis) recreational functions would be combined with agrarian ones (Fig. 2). A significantly more complex spatial dynamics of the species is presented on the periphery of the influence of urban ecosystems where a new continually-disperse form of resettlement is gradually formed. In this case, the hexagonal lattice (according to Walter Crystaller) may be the end state of the whole system.

- The main feature of the proposed model is that the greatest dispersion is placed on the periphery, unlike the earlier ones [Hagget, 1968; Izard, 1964]. This generally corresponds to the state of population dynamics observed in other species in Living Nature with a rather precise definition of One Person Homo sapiens habitat/ecotope [Gorshkov, 1995] with a contact type of delimitation and thus with the formation of transitional bands or ecotones. Modifications of spatial relationships in the proposed model can be varied. However, the main direction of the interaction of nature and society is radically changing from anthropocentric to adapted one. Aspiration to the state of the noosphere with a positive (in favor of nature) material-energy balance must be carried out by Man within the spatial boundaries of the social-natural systems which substantially represent ecosystems and have a double character of boundaries. That is, these are synergistic combinations of natural and social systems that are already evolving according to their own laws [Sonko, 2006]. 
- In the understanding of the socio-natural system consciously placed noosphere content, based on the fact that the noosphere is the sphere of reason that is still formed, and the process of spatial development of social-natural (noospheric) systems is a process of noosphere genesis. Approximation of the territorial organization of society to "sustainability" is proposed to be implemented in the form of possible scenarios (Tabl.1) at different spatial levels using special indicators [Sonko, 2018b]. The existing strategy for the formation of the ecological network should cover the meso- and macro levels. At the micro level, it is necessary to introduce a strategy coordinated with the noospheric dynamics for combining nature ecosystems and agricultural ecosystems in the directions proposed by the author. In this case, the main conditionally sustainable development is performed that is such a change in the structure and functions of natural ecosystems by a person that would leave them capable of self-reproduction.

- As an approach to sustainable development, the priority development of agricultural ecosystems, as analogues of the noosphere ecological niche of Homo sapiens, is foreseen, with the subsequent need for the "insertion" of the administrative-territorial division at their borders. Since it is then that the chorological content of the interaction of nature and society will be approximated to the optimal [Sonko, 2006].

- For the concept implementation, a model of socio-natural interaction was developed, based on the principle of spatial rotation of the functions of agricultural and urban ecosystems with the desire not to barrier but to the contact (ecotone) type of boundaries between natural and antropized elements (Fig. 2). In this case, the main direction of the interaction of nature and society is radically changing from anthropocentric to adapted one. Given the main content of the above concept, we must agree with the opinion of Kim Losev and Victor Gorshkov [Gorshkov, 1995; Losev, 2003] that the main guarantee of the "noosphere" of nature should not be quotas for carbon dioxide emissions (Kyoto Protocol) but the success in individual countries of the mechanism of self-reproduction of natural ecosystems.

- Regarding agricultural ecosystems, according to current estimates, the carbon emission as the main contributor to the greenhouse effect of world agriculture by $10 \%$ exceeds its emissions from fossil fuel combustion [Losev, 2003]. Consequently, modern agriculture is the main contributor to the greenhouse effect and this impact will continue to grow in the context of the economic and demographic crisis. The practical solution to these conflicts is the rebirth of such communities in the countryside that would be close to natural ecosystems by the type of their spatial existence (Table 1). A radical change in the spatial existence of mankind in the direction of a natural economy will help stabilize population growth and also make nature management adapted to natural ecosystems [Sonko \& Maksimenko, 2015].

\footnotetext{
${ }^{9}$ Trying to reconcile the modern trends in the development of global ecology with classical works, the author had nothing left but to put the sign of the equation between the "noosphere» and «sustainable development." The author did not find signs of a scientific discussion about the incorrectness of such a comparison on the pages of scientific literature.
} 


\section{Table 1. Scenarios for the transition to sustainable development (noosphere) ${ }^{10}$}

\begin{tabular}{|c|c|c|c|c|}
\hline \multirow{2}{*}{$\begin{array}{l}\text { Scenario } \\
\text { elements }\end{array}$} & \multicolumn{4}{|c|}{ Scenarios and concepts of nature management } \\
\hline & Conservative & Centrist & Scientistic & Noospheric \\
\hline $\begin{array}{l}\text { Population } \\
\text { limit of } \\
\text { the planet } \\
\text { (billion } \\
\text { people) }\end{array}$ & $0.5-1.5$ & $8-12$ & $30-50$ & $8-10$ \\
\hline $\begin{array}{l}\text { Urbanization } \\
\text { nature }\end{array}$ & $\begin{array}{l}\text { The level of } \\
\text { urbanization } \\
\text { is decreasing, } \\
\text { instead of } \\
\text { metropolises } \\
\text { and large cities, } \\
\text { econets are } \\
\text { developing }\end{array}$ & $\begin{array}{l}\text { Gradual } \\
\text { stabilization of } \\
\text { the number and } \\
\text { size of cities, } \\
\text { as well as the } \\
\text { population of } \\
\text { the Earth }\end{array}$ & $\begin{array}{l}\text { The level of } \\
\text { urbanization is } \\
\text { increasing, large } \\
\text { cities are becoming } \\
\text { ecological, } \\
\text { including } \\
\text { megacities }\end{array}$ & $\begin{array}{l}\text { The level of } \\
\text { urbanization is } \\
\text { decreasing, there } \\
\text { are cities but } \\
\text { they cease to } \\
\text { play the role of } \\
\text { "social being", } \\
\text { the network } \\
\text { of ecological } \\
\text { settlements is } \\
\text { expanding }\end{array}$ \\
\hline $\begin{array}{l}\text { Change } \\
\text { the size of } \\
\text { the world's } \\
\text { power } \\
\text { consumption }\end{array}$ & $\begin{array}{l}\text { Decreasing by } \\
6-10 \text { times }\end{array}$ & $\begin{array}{l}\text { Increasing by } \\
2-3 \text { times }\end{array}$ & $\begin{array}{l}\text { Increasing by } 10 \text { or } \\
\text { more times }\end{array}$ & $\begin{array}{l}\text { It is stabilized at } \\
\text { the existing level } \\
\text { but the energy } \\
\text { consumption } \\
\text { structure is } \\
\text { radically changing } \\
\text { towards energy } \\
\text { saving. }\end{array}$ \\
\hline $\begin{array}{l}\text { Structure } \\
\text { of power } \\
\text { economy }\end{array}$ & $\begin{array}{l}\text { RES-based } \\
\text { energy } \\
\text { (Renewable } \\
\text { Energy) }\end{array}$ & $\begin{array}{l}\text { Poly power } \\
\text { economy: } \\
\text { atomic, RES } \\
\text { based and } \\
\text { thermal one }\end{array}$ & $\begin{array}{l}\text { Predominance of } \\
\text { nuclear power }\end{array}$ & $\begin{array}{l}\text { Basic power } \\
\text { is hybrid and } \\
\text { alternative; } \\
\text { supporting power } \\
\text { is atomic. }\end{array}$ \\
\hline $\begin{array}{l}\text { Agriculture } \\
\text { nature: }\end{array}$ & Saving & $\begin{array}{l}\text { Moderately } \\
\text { saving }\end{array}$ & Too intense & $\begin{array}{l}\text { Economical and } \\
\text { natural }\end{array}$ \\
\hline $\begin{array}{l}\text { - share of } \\
\text { arable land }\end{array}$ & Low $(35-40 \%)$ & $\begin{array}{l}\text { Moderate (up to } \\
50 \% \text { ) }\end{array}$ & High (over 60\%) & Low $(35-40 \%)$ \\
\hline
\end{tabular}

\footnotetext{
${ }^{10}$ Characteristics of individual scenarios are given below
} 


\begin{tabular}{|c|c|c|c|c|}
\hline $\begin{array}{l}\text { - system of } \\
\text { agriculture }\end{array}$ & $\begin{array}{l}\text { Organic } \\
\text { system. Mineral } \\
\text { fertilizers and } \\
\text { pesticides are not } \\
\text { used }\end{array}$ & $\begin{array}{l}\text { Compromise } \\
\text { system. Mineral } \\
\text { fertilizers and } \\
\text { herbicides } \\
\text { are used in } \\
\text { moderate doses. }\end{array}$ & $\begin{array}{l}\text { Intense system. } \\
\text { Greenhouses, } \\
\text { high doses of } \\
\text { mineral fertilizers, } \\
\text { irrigation and } \\
\text { mono crops are } \\
\text { widely used. }\end{array}$ & $\begin{array}{l}\text { Highly adaptive } \\
\text { system to local } \\
\text { conditions, with a } \\
\text { minimum amount } \\
\text { of energy subsidies }\end{array}$ \\
\hline $\begin{array}{l}\text { - variety of } \\
\text { farm animals } \\
\text { and type of } \\
\text { feeding }\end{array}$ & $\begin{array}{l}\text { High variety, } \\
\text { extensive } \\
\text { feeding at } \\
\text { the expense } \\
\text { of natural } \\
\text { forage farms } \\
\text { and growth } \\
\text { promoters are } \\
\text { not used. }\end{array}$ & $\begin{array}{l}\text { Moderate } \\
\text { diversity, } \\
\text { integrated feed } \\
\text { rations with } \\
\text { arable feeding } \\
\text { and growth } \\
\text { stimulants are } \\
\text { not used }\end{array}$ & $\begin{array}{l}\text { Low diversity, } \\
\text { intensive fattening } \\
\text { of cattle, pigs, } \\
\text { poultry with } \\
\text { arable food and } \\
\text { widespread use of } \\
\text { growth stimulants } \\
\text { and other } \\
\text { "biochemistry" }\end{array}$ & $\begin{array}{l}\text { Diversity in } \\
\text { accordance with } \\
\text { local traditions, } \\
\text { complicated } \\
\text { feeding, adapted } \\
\text { to local conditions } \\
\text { (provided that the } \\
\text { share of "fodder } \\
\text { plow" is not } \\
\text { exceeded by more } \\
\text { than } 15 \% \text { ). }\end{array}$ \\
\hline $\begin{array}{l}\text { - transgenic } \\
\text { varieties and } \\
\text { breeds }\end{array}$ & Not used & $\begin{array}{l}\text { Used } \\
\text { moderately }\end{array}$ & Used widely & $\begin{array}{l}\text { Transgenic and } \\
\text { introduced plants } \\
\text { either excluded at } \\
\text { all or substantially } \\
\text { do not affect } \\
\text { the structure of } \\
\text { cultural phyto- and } \\
\text { zoocenosis }\end{array}$ \\
\hline $\begin{array}{l}\text { - charac- } \\
\text { teristics of } \\
\text { consumption } \\
\text { of agricultur- } \\
\text { al products }\end{array}$ & $\begin{array}{l}\text { Prevailing } \\
\text { abandonment of } \\
\text { animal proteins } \\
\text { in favor of plant } \\
\text { ones }\end{array}$ & $\begin{array}{l}\text { The diet is close } \\
\text { to the current } \\
\text { one }\end{array}$ & $\begin{array}{l}\text { The diet is } \\
\text { "distorted" towards } \\
\text { the further increase } \\
\text { in the consumption } \\
\text { of animal proteins }\end{array}$ & $\begin{array}{l}\text { The diet is } \\
\text { balanced and meets } \\
\text { local traditions }\end{array}$ \\
\hline $\begin{array}{l}\text { Basic } \\
\text { structural } \\
\text { materials } \\
\text { and mineral } \\
\text { resources }\end{array}$ & Secondary & $\begin{array}{l}\text { Primary and } \\
\text { secondary in the } \\
\text { development of } \\
\text { resource-saving } \\
\text { technologies }\end{array}$ & $\begin{array}{l}\text { Replacement } \\
\text { of exhaustive } \\
\text { resources } \\
\text { with their new } \\
\text { equivalents }\end{array}$ & $\begin{array}{l}\text { Replacement } \\
\text { of exhaustive } \\
\text { resources } \\
\text { with their new } \\
\text { equivalents that } \\
\text { will be capable } \\
\text { of biodegradation } \\
\text { upon completion } \\
\text { of use }\end{array}$ \\
\hline
\end{tabular}




\begin{tabular}{|l|l|l|l|l|}
\hline $\begin{array}{l}\text { Environmen- } \\
\text { tal pollution }\end{array}$ & $\begin{array}{l}\text { Minimal } \\
\text { pollution due to } \\
\text { the closure of all } \\
\text { environmentally- } \\
\text { friendly } \\
\text { industries } \\
\text { and the } \\
\text { implementation } \\
\text { of non-waste } \\
\text { technologies }\end{array}$ & $\begin{array}{l}\text { It stays at the } \\
\text { current level }\end{array}$ & $\begin{array}{l}\text { Moderate pollution } \\
\text { due to low-waste } \\
\text { technologies, } \\
\text { improved } \\
\text { wastewater } \\
\text { treatment facilities } \\
\text { and disposal of } \\
\text { highly hazardous } \\
\text { waste }\end{array}$ & $\begin{array}{l}\text { Minimal } \\
\text { pollution due to } \\
\text { deurbanization, } \\
\text { transition to new } \\
\text { construction } \\
\text { materials, } \\
\text { reduction of the } \\
\text { general level of } \\
\text { consumption and } \\
\text { the introduction } \\
\text { of a significant } \\
\text { share (up to 40\% } \\
\text { of GDP) of the } \\
\text { natural economy. }\end{array}$ \\
\hline $\begin{array}{l}\text { Biodiversity } \\
\text { protection }\end{array}$ & $\begin{array}{l}\text { Complete } \\
\text { retention }\end{array}$ & $\begin{array}{l}\text { Saving larger } \\
\text { part }\end{array}$ & Saving 50-70\% & $\begin{array}{l}\text { Gradual } \\
\text { abandonment } \\
\text { of agricultural } \\
\text { ecosystems in their } \\
\text { present form in } \\
\text { favor of adapted } \\
\text { forms of nature } \\
\text { management }\end{array}$ \\
\hline $\begin{array}{l}\text { Share of } \\
\text { protected } \\
\text { natural } \\
\text { territories on } \\
\text { the planet }\end{array}$ & $70 \%$ & $33 \%$ & $\begin{array}{l}\text { Less than } 10 \% \\
\text { introduction of } \\
\text { protected areas } \\
\text { is gradually } \\
\text { disappearing }\end{array}$ \\
\hline
\end{tabular}

Conservationism, as an outlook for the future, arose as a protest against scintillation and based on the slogan "Back to Nature!" because it goes from the point that the increase in the human's impact on nature leads mankind to death. Conservationism is rooted in alarmism (from English alarm). The alarmists believed that an ecological crisis with tragic consequences for humanity up to complete extinction was inevitable. The most prominent evolutionist Jan Batiste Lamarck believed that the purpose of the person is to destroy himself having made his life environment inapplicable in advance. In those same years, Tomas Malthus predicted the inevitability of overpopulation and hunger. The ideology of alarmism was imbued with the activities of the Roman club in the 60's and 80's. Conservative views are clearly or implicitly adhered to by most Russian environmentalists (Victor Gorshkov, Victor Danilov-Danilian, Alexej Yablokov, Kim Losev, Arkady Ursul, etc.). The central idea of the preservationist scenario is to approve the need for depopulation. It is reducing the planet's population to $0.5-1.5$ billion people.

Centrism is a scenario for building a sustainable development society and it combines elements of several scenarios. The main idea of this scenario was expressed by Nikita Moiseev (1990) in his ideas about the co-adaptation of man and biosphere. With such coadaptation, the biosphere will become a "quasi-stable state" with preservation of the main biosphere cycles of matter. The noosphere in this case is understood not as "the sphere of 
reason" but as "sphere of reasonableness".

Scientism. The cornerstone of scientism is faith in the full cognition of the world and on this basis in the possibility of solving any problems facing mankind (energy, resource, technological, etc.). In the United States, this view of the world is also called cornucopianism (from the Latin cornucopia). In domestic science, the supporters of scientism are Konstantin Korsak and Yuri Korsak [Korsak \& Korsak, 2012].

Noospherism is the doctrine of human society, which is based on noosphere principles that consist in the comprehensive adaptation of nature to natural mechanisms. There are objective prerequisites for this. Therefore, in rural areas of most countries, people are put on the brink of survival that causes a return to the natural economy and the need to harmonize with the natural landscapes in which the family lives. There are new public initiatives "return to nature" such as the ecological movement "Clinking cedars of Russia", production of organic products, creation of ecological settlements, etc. Consumption of natural substances and energy and the generation of waste of life occur on ecosystem principles. Consumption of the ecological resource of the planet is "stretched" in time in order to ensure the proper conditions for the life of future generations.

The spatial, ecological and social life of man becomes a form of combination of local age traditions of nature use and the latest technologies in which the entropy limitations are removed. The result is a gradual return of the energy consumption by the human population to a level of $1 \%$. It is in accordance with the laws of the ecosystem organization of populations of living organisms. The main ideas of noospherism, adapted to the balanced nature management, correlate with the above autors noospheric ecosystems concept.

\section{Conclusions}

1. The primary spatial-temporal unit of the noosphere genesis is agricultural ecosystem exists and develops.

2. Finding and further studying of spatial-temporal dynamics is possible at the microspatial level, ranging from the boundaries of peasant farming/farm.

3. Effective steps towards the solution of the global environmental problem are possible in the case of the approximation of economic boundaries of agricultural ecosystems to their natural boundaries.

4. The administrative-territorial structure of any country should be built in conjunction with the natural boundaries of agricultural ecosystems, which will enable ecologically and economically to manage nature use.

5. The concept of noospheric ecosystems, developed by the author, is a more lenient version of the Alarmist concept but following it will allow us to harmonize tense relations of nature and society today over a reasonable time (the life of one generation).

The author intends to consider what exactly is to be done in order to implement an adapted strategy for nature management in his subsequent works, since restrictions on the scope of this article do not allow this to be done. In particular, it is planned to consider the system of biosphere constants, which values a person, should not exceed in the process of nature management.

\section{References}

Arsky, Yuri, Victor Danilov-Danilyan, Michail Zalikhanov, Kiril Kondratiev, Vladimir Kotlyakov, and Kim Losev. Environmental problems: what happens, who is to blame 
and what to do? Moscow: MNEPU, 1997. (in Russian)

Baburin, Vyacheslav. Influence of the geographical specificity of the distribution of innovative waves on the territorial organization of society. Moscow: Drofa, 1999.

Bazaluk, Oleg. The Philosophy of Cosmos: the Place of Human at the Scale of Earth and Cosmos. Philosophy and Cosmology, 16, 2016: 28-42. (in Russian)

Biosphere. Evolution. Space. Time. Moscow: Progress, 1988. (in Russian)

Chayanov, Alexander. Peasant farming. Selected works. Moscow: Economics, 1989. (in Russian)

Deleuze, Gilles, and Felix Guattari. Rizoma. A Thousand Plateau. Online almanac "East», November-December Issue11/12 (35/36), 2005: 48-56.

Galli, Alessandro, Thomas Wiedmann, Ertug Ercinc, Doris Knoblauchd, Brad Ewinge, and Stefan Giljumf. Integrating Ecological, Carbon and Water footprint into a "Footprint Family" of indicators: Definition and role in tracking human pressure on the planet. Ecological Indicators, 16, 2012: 100-112.

Golubets, Myhaylo. Ecosystemology. Lviv: Polly, 2000. (in Ukrainian)

Gorshkov, Victor. Physical and biological basis of life sustainability. Moscow: VINITI, 1995. (in Russian)

Gumilev, Lev. Ethogenesis and the Earth's biosphere. Moscow: Institute DI DIK, 1997. (in Russian)

Hagget, Piter. Spatial Analysis in Economic Geography. Moscow: Progress, 1968. (in Russian)

Khrutsky, Konstantin. Introduction to cosmic (universal) anthropology. Moscow: Institute of Philosophy of the Russian Academy of Sciences Press, 1999. (in Russian)

Korsak, Konstantin, and Yuri Korsak. Nootehnologii — the basis of positive eschatology and sustainable development. Relga. Electronic Journal, 15 (253), 2012. (In Russian)

Krushanov, Alexander. Universal paradigm of ecology. Philosophy of science. Issue 7: Formation of a modern natural science paradigm, 2001: 13-28.

Lazarev, Sergey. Diagnosis of karma. St. Petersburg: Lenizdat, 2000. (In Russian)

Losev, Kim. The budget of anthropogenic carbon and the role of ecosystems in its emissions and runoff on a global and continental scale. Countries and regions on the way to balanced development. Collection of scientific papers. Kyiv, 2003. (In Russian)

Mironenko, Nicolay, and Michail Sorokin. Factors of compression of geographical space. Geography, 48, 2001: 34-40. (in Russian)

Pozdnyakov, Dmitry, Valentin Tikunov, and Alexej Fedotov. Development and mapping of integral indicators of sustainable development of the countries of the world. Vestnik Moscowskogo Universiteta, Geography, 5 (2), 2003: 20-29. (in Russian)

Reimers, Nicolay. Ecology. Theories, laws, rules, principles and hypotheses. Moscow: Young Russia, 1994. (In Russian)

Reteyum, Alexej. Earth worlds. Moscow: Myis1, 1987. (In Russian)

Rogachev, Sergey. Spatial inversions. Ten situations for analysis. Geography (27), 1999: 15-23. (in Russian)

Shnirelman, Victor. The emergence of a productive economy. Moscow: Science, 1989. (in Russian)

Shvebs, Henrich. Enio-Earth Sciences. Statement of the question. Ukrainian Geographical Magazine (4), 1998: 41-46. (in Russian)

Sonko, Sergiy. Agricultural districts of the Kharkiv Region: Geographical Issues Environmental Consequences. Dniprop. Univer.bulletin. Geology, geography, 26 (1), 
2018a: 165-175. (in Ukrainian)

Sonko, Sergiy. Fundamental principles of noospheric nature management in the context of the sustainable development concept. Vestnik KEI KNEU, 8, 2006: 74-87. (in Ukrainian)

Sonko, Sergiy, and Nadija Maksimenko. Spatial and temporal mechanisms of anthropogenic expansion of agrolandscapes. Man and environment, 2 (15), 2013: 5-21. (in Ukrainian)

Sonko, Sergiy. Reform of the administrative-territorial system on the principles of noosphere development. Materials of the IX All-Ukrainian scientific Talyev readings, 2013: 159161. (in Ukrainian)

Sonko, Sergiy, and Mykola Skrynko. Infrastructure in a transitional economy. Monograph. Kharkov: Eco-graph, 2004. (in Ukrainian)

Sonko, Sergiy and Nadiya Maksimenko. Ecological bases of balanced nature use in the agro-sphere: educational manual. Kharkiv: Vasily Karazin National University Press, 2015. (in Ukrainian)

Sonko, Sergiy. Spatial development of social-natural systems: the path to a new paradigm: Monography. Kiyv: Nica Centr, 2003. (in Ukrainian)

Sonko, Sergiy. Sustainable development: 25 years of hope and disappointment. Sustainable development - state and prospects, 343, 2018b: 59-63. (in Ukrainian)

Sonko, Sergiy. The concept of noospheric ecosystems as a continuation of the ideas of V.I. Vernadsky. Noosphere and civilization, 8-9 (11), 2010: 230-241. (in Ukrainian)

Sozinov, Olexij, and Sergiy Sonko. Agroecosystem. Ecological Encyclopedia, T. 1. Kyiv: TOV Center for Environmental Education and Information, 2006. (in Ukrainian)

Timofeev, Dmitry. City-ecosystem. Moscow: Media-Press, 1997. (in Russian)

Topchiev, Olexander. Geographical bases of geoecology. Odesa: Astrorrint, 2001. (in Russian)

Ursul, Arkady, and Tatiana Ursul. Universal (Global) Evolutionism. Philosophy and Cosmology, 20, 2018: 33-41. https://doi.org/10.29202 / phil-cosm / 20/3.

Vavilov, Nicolay. Origin and geography of cultivated plants. Lviv: Science, 1987. (in Russian)

Vazhenin, Alexander. Hierarchies of central places and patterns in the development of settlement systems. Proceedings of the Academy of Sciences. Geographic series, 5, 2002: 64-71. (in Russian)

Yablokov, Aleksey, Vladimir Levchenko, and Anatoliy Kerzhentsev. Ocherki biosferologii. 1. Vyihod est: perehod k upravlyaemoy evolyutsii biosferyi (The Decision Exists: Transition to Controlled Evolution of the Biosphere). Philosophy and Cosmology. Vol. 14, 2015: 91-117. (in Russian)

Yablokov, Aleksey, Vladimir Levchenko, and Anatoliy Kerzhentsev. Biosfera kak zhivaya sistema. Ob osobennostyah evolyutsionnogo protsessa na biosfernom urovne (The Biosphere as a Living System. On Peculiarities of the Evolutionary Process on the Biosphere Level). Philosophy and Cosmology. Vol. 17, 2016: 152-175. (in Russian)

Yablokov, Aleksey, Vladimir Levchenko, and Anatoliy Kerzhentsev. The Biosphere as a Living System. On the Harmonization of Human and Biosphere Relationship. Philosophy and Cosmology, 18, 2017: 52-83. (in Russian)

Yakovleva, Svetlana. Functions of infrastructure in the development of old industrial regions of Russia. Proceedings of the Academy of Sciences. Geographic series, 4, 2002: 5864. (in Russian)

Yuzvishin, Ivan. Fundamentals of Informatiology. Moscow: High School, 2001. (in Russian) 